\title{
Early childhood care and education trainees' perspectives of their career path
}

\author{
Roznim Mohamad Rasli ${ }^{1}$, Nor Azah Abdul Aziz ${ }^{2}$, Erni Marlina Saari ${ }^{3}$, Mazlina Che Mustafa ${ }^{4}$, Sopia \\ Md Yassin 5 \\ ${ }^{1,2,3}$ Faculty of Art, Computing and Creative Industry, Sultan Idris Education University, Tanjung Malim, Malaysia \\ ${ }^{4,5}$ National Child Development Research Centre, Sultan Idris Education University, Tanjung Malim, Malaysia
}

\begin{tabular}{l} 
Article Info \\
\hline Article history: \\
Received Sep 12, 2020 \\
Revised Jun 13, 2021 \\
Accepted Jul 28, 2021 \\
\hline
\end{tabular}

\section{Keywords:}

Career path-planning Early childhood care Knowledge and skills Professional development Teacher competency

\begin{abstract}
Education, either formal or informal, plays an important role to help the masses. As such, educators, especially trainees, are entrusted to teach young generations all important elements, principles, or concepts in a wide range of disciplines. Surely, such an undertaking, especially for early childhood care and education, requires quality teachers. In this regard, existing early childhood care and education modules or curricula should be periodically reviewed and revamped (if necessary) to help produce competent teachers who are excellent in all aspects encompassing content, pedagogical, and technological knowledge. This paper discusses the professional growth and development of trainees in early childhood care and education (ECCE) in terms of short- and long-term goals, missions, and career path-planning. The paper also elaborates on the relevant training workshops, courses, modules, and curricula that can be implemented to help improve their practical skills. The discussion also highlights the importance of incentives, such as attractive salaries, bonuses, acknowledgments, and awards, from employers that can not only motivate trainees but also advance their professional growth and development. Certainty, strong development knowledge, practical skills, and experiences can help such trainees to be become highly competent, which can significantly contribute to nation-building efforts in Malaysia.
\end{abstract}

This is an open access article under the CC BY-SA license.

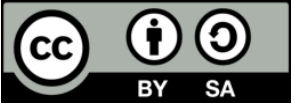

\section{Corresponding Author:}

Nor Azah Abdul Aziz

Faculty of Art, Computing and Creative Industry

Sultan Idris Education University

Tanjung Malim, Perak Darul Ridzuan 35900, Malaysia

Email: azah@fskik.upsi.edu.my

\section{INTRODUCTION}

Many scholars have debated the concept of learning since thousand years ago. For example, Marton and Booth [1] eloquently state that "learning is about how we perceive and understand the world, about making meaning." From a practical perspective, Fink [2] argues that the impact of learning will result in a number of changes that can significantly affect our lives. Through learning, the behaviours of humans and the environments in which they inhabit will change, affecting the causal relationship between the two [3]-[5]. From the cognitive perspective, Baden and Major [6] asserts that learning is based on 'surface' and 'deep' approaches in order to develop more sophisticated approaches to thinking, called sophisticated thinking.

In this regard, the educational sector plays a crucial role in providing quality education to build better nations by striving for excellence. A study by Selvaraj, et al. [7] indicates that four main factors can help improve the Malaysian educational system, namely teaching and learning, governance, globalization, and knowledge-based society. Together, these factors can ensure quality assurance, employability, and 
English language competency of Malaysian students. Clearly, efforts to uplift the quality of education in Malaysia have to be given top priority to help provide excellent learning opportunities for students at all levels. Arguably, only through such efforts that the aims to produce the required knowledgeable and skillful workforce, as outlined in the Malaysian Education Blueprint 2013-2025, can be met as planned [8]-[11].

As such, they were fulfilling such requirements entails making important changes to existing practices in the educational sector. For example, educators, being one of the key players in education, need to have not only hard skills but also soft skills. Put simply, their intellectual, emotional, and physical attributes have to be well developed and balanced, especially in dealing with early childhood care and education (ECCE). In the Malaysian context, ECCE encompasses both formal and informal education and care, which are conducted at two main types of centers, namely Childcare Centre (Taman Asuhan Kanak-Kanak TASKA) and Preschool or Kindergarten (Taman Didikan Kanak-Kanak - TADIKA) involving children whose ages range from birth to three years and from four to six years, respectively [12]-[15].

Presently, ECCE (generally referred to as preschool system) is not part of the Malaysian formal educational system that mandates compulsory enrolment of such children [16]. Nonetheless, its importance cannot be emphasized enough as it provides early exposure for young children to the school life and makes them independent. As one of the Malaysian government initiatives conducted through its Ministry of Education, the preschool education is structured based on several successive phases to ensure all children will have equal opportunity and a head start for early education. Thus, for children to experience quality ECCE, early childhood educators, including teacher trainees, need to be knowledgeable and competent, which entails them to undergo professional growth and development on a continual basis. Admittedly, such trainees need to learn new knowledge, acquire new competencies, and attain short- and long-term goals through sound planning of their career path [17]-[20]. To date, the main issues of ECCE in Malaysia are mainly concerned with quality, qualification, language and ethnicity or race [21].

Career pathway refers to an organized approach for career planning by charting a course to identify occupational interests, determine education and training needs, and establish an action plan for reaching career goals [22]. Creating a career pathway begins by evaluating the current state of career awareness and readiness. Identifying a potential career opportunity based on interests, skills, work experiences, and work values are the motivation behind this evaluation. Work values (such as working conditions and potentials of job advancement) are worth identifying because of their connections to career satisfaction. After pinpointing a specific career choice, a reasonable, workable pathway needs to be ascertained with the help of appropriate resources. Figure 1 shows the components of the career development process [23]-[26].

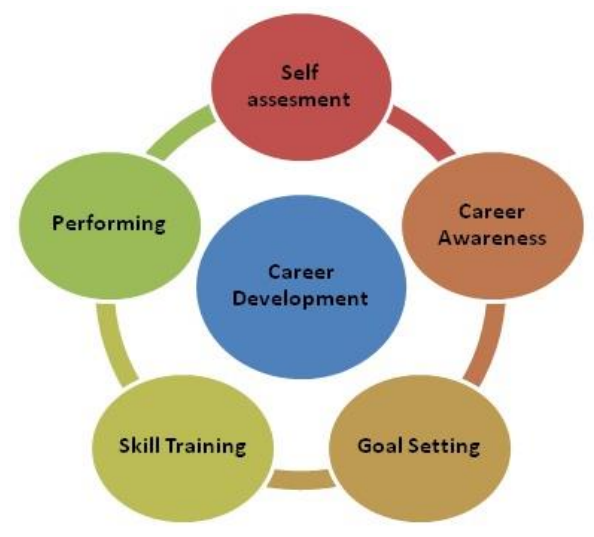

Figure 1. Career development process [22]

A career pathway is directly linked to the goals and objectives set by an individual who starts with self-actualization and self-assessment of one's interests and capabilities, which is then matched with available options [22]. Surely, educators require adequate training by going through professional workshops or courses to improve their knowledge and acquire new skills, which can help them effectively teach children placed in nurseries and kindergartens. Specifically, they need to learn and master all aspects of the ECCE program to become good early childhood education teachers [27]-[30]. Additionally, by learning other aspects of education, such as leadership, good governance, time management, communication management, and team management, they can determine and shape their career paths [22], [30]. In this regard, educators must identify and take relevant courses to improve their professionalism in the educational realm. 
Several research findings indicate that income and career path are two external factors that wield significant differential impacts on ECCE educators' career decision. For example, ECCE educators with a higher income and a desirable career path will likely to stay committed with their profession in the long run. By contrast, some findings unveil that several internal factors, such as professionalism and self-esteem, are not important determinants of career decision among ECCE educators. Despite concerted efforts by the Malaysian government, turnover rates of early childhood educators were alarming high as highlighted by 2000-2015 data of Malaysia's Ministry of Education [31]. Surely, such a revelation portends bad news to the ministry's efforts to produce a sufficient number of such professionals.

In light of the above problems, this paper discusses a review on the professional career development of early childhood education educators by focusing on their continual professional growth and development based on short- and long-term goals and their career path planning. In particular, the discussion centers on the findings of studies of pre-service teachers and other related works of literature. The discussion of this paper is organized in several sections. Section 1.0 discusses the main elements of education, concepts of learning, and the teacher trainees' perspective of their professional growth, development, and career path. Then, in Section 2.0, the discussion delves into the specific methodology applied for a preliminary survey (as reported in this paper). Later, in Section 3.0, the paper elaborates the findings regarding continual professional growth and development and career path plans of trainees. Finally, Section 4.0 summarizes the discussion by highlighting the main points raised.

In terms of short- and long-term priorities, missions, and career path preparation, this paper addresses the professional growth and advancement of trainees in early childhood care and education (ECCE). The paper also addresses the required training seminars, courses, modules, and curricula that can be placed in place to further develop their practical skills.

\section{RESEARCH METHOD}

The methodology used in this study involved several steps, namely interview, transcription, coding, intra-and inter-group comparison, categorization, and summarization of quantitative data of pre-service teachers, which helped the researchers to analyze such data descriptively. Figure 2 shows the overall flow of the methodological steps of this study.

\begin{tabular}{|c|}
\hline Interview \\
$\downarrow$ \\
\hline Transcription \\
\hline$\downarrow$ \\
\hline Coding \\
$\downarrow$ \\
\hline Intra- and Inter-Group Comparison \\
\hline$\downarrow$ \\
\hline Categorization \\
$\downarrow$ \\
\hline Summarization
\end{tabular}

Figure 2. The overall flow of the methodological steps

The first step involved a series of interviews in which several practitioners were recruited to provide their perspectives on the importance of professional growth and development in their careers. Such an approach is deemed appropriate to reveal important information regarding issues or problems that prevail in a particular program or situation [30]. Specifically, the interviewees were made up of four Sijil Kemahiran Malaysia (SKM) providers and seven Kursus Asuhan PERMATA (KAP) providers (their inputs served as the qualitative data of the pre-service teachers). Then, these data were transcribed into more meaningful transcripts, known as the national quality framework (NQF) comprising eight main standards, separated into several components and indicators.

The national quality framework (NQF) is part of the early childhood education and child care policy of the Australian Government, which focuses on providing high-quality, available and affordable integrated early childhood education and child care to Australian families. The NQF seeks to enhance quality and drive continuous improvement and continuity in the services of education and care by: a national legislative framework; a national quality standard; a national quality rating and assessment process; a new national body called the Australian Children's Education \& Care Quality Authority. 
The inter-rater reliability technique was then applied involving three experts on qualitative research (with vast experience in interviewing techniques) to validate the NQF data. They performed the validation process separately by using a coding scheme developed by the researchers to help them identify and categorize relevant patterns or thematic elements based on relationships of keywords, which helped in the efficient analysis, organization, and interpretation of the research findings. Finally, the findings were summarized based on the research objectives.

\section{RESULTS AND DISCUSSION}

The findings showed that the trainees had a clear picture of their short-and long-term goals and the need for career path planning and professional growth and development. The awareness is vital not only for the behavioral transformation but also affects attitudinal change and improved intellectual capacity which is even more significant to boost up professionalism levels [32]. In terms of career path planning, the findings indicated that the trainees were aware of the direction that they had to follow in advancing their career, starting by being a teacher, and then by becoming a supervisor, and finally by becoming a manager or an owner of a childcare center or a kindergarten. This is in line with Evans [33] assertion which recommends that ECCE be formed by professional preschool teachers and professional childcare providers.

These trainees were also able to differentiate the specific requirements of various professions in ECCE and foresee new job opportunities relating to ECCE. In other words, these trainees can appropriately re-defined and differentiate the scope and professional roles of ECCE, conceptualized as multi-faceted and multi-disciplinary [34]. Figure 3 shows the path of the career advancement of ECCE teacher trainees.

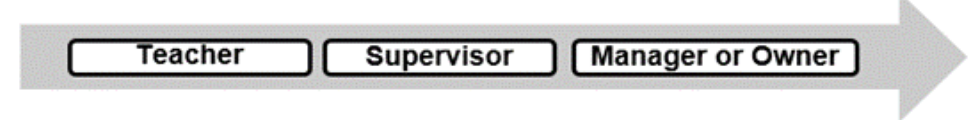

Figure 3. The path of the career advancement of ECCE teacher trainees

As highlighted, the highest attainment in the ECCE profession is to own and manage a nursery, kindergarten, or childcare center. Admittedly, to attain such a feat is not easy, as trainees may have to deal with a myriad of issues and challenges. Obviously, they need to learn the managerial and administrative aspects required to run such a center. Table 1 summarizes the constraints and recommendations in running a childcare center or kindergarten.

Table 1. The constraints and recommendations in running a childcare center or kindergarten

\begin{tabular}{ll}
\hline \multicolumn{1}{c}{ Constraints } & \multicolumn{1}{c}{ Recommendations } \\
\hline $\begin{array}{l}\text { Restrictions in the operation of kindergartens or childcare } \\
\text { centers. }\end{array}$ & $\begin{array}{l}\text { Supervise the management of nurseries, kindergartens, and pre- } \\
\text { schools. }\end{array}$ \\
$\begin{array}{l}\text { The requirement for management and administrative advice } \\
\text { before and after the opening of kindergartens or childcare } \\
\text { centers. }\end{array}$ & $\begin{array}{l}\text { Establish nurseries for children with special needs. } \\
\text { accreditation. }\end{array}$ \\
$\begin{array}{l}\text { Difficulty in managing stress in management. } \\
\text { Low-profit rates and poor customer satisfaction. }\end{array}$ & $\begin{array}{l}\text { Do not enforce children to learn and play. } \\
\text { Remind yourself of responsibility, be ethical and be self-fulfilling }\end{array}$ \\
$\begin{array}{l}\text { The high unemployment rate among postgraduate educators. } \\
\text { Restrictions in carrying out certain tasks by male caregivers. } \\
\text { Teachers have to put their children to the management to } \\
\text { update their management work. }\end{array}$ & $\begin{array}{l}\text { Avoid interfering with personal issues with the management and } \\
\text { administration of nursing homes. }\end{array}$ \\
$\begin{array}{l}\text { Some nursing home employers only benefit from childcare. } \\
\text { Difficulties in getting accurate information about ECCE } \\
\text { management. }\end{array}$ & $\begin{array}{l}\text { Use a variety of teaching aids and set up a comfortable area for } \\
\text { leisure activities for children. }\end{array}$ \\
& $\begin{array}{l}\text { Requires efficient management and management of nursing homes. } \\
\text { Teachers need to be creative to improve student learning. }\end{array}$ \\
\hline
\end{tabular}

For continual professional growth and development, nine factors were identified as: further study; workshops or courses; salary; bonus; acknowledgment awards; ECCE curriculum; awareness; knowledge, exposure, skills, and experiences; and sports. As suggested by Neuman, et al. [31] and Foong, et al. [35], the fundamental nature of ECCE quality improvement and access is shaped by competent development, welltrained, and well-supported teachers, as well as the well-being of teachers. Table 2 highlights the detail of each factor relating to the professional growth and development of trainees. 
Table 2. The description of key factors in the continual professional development

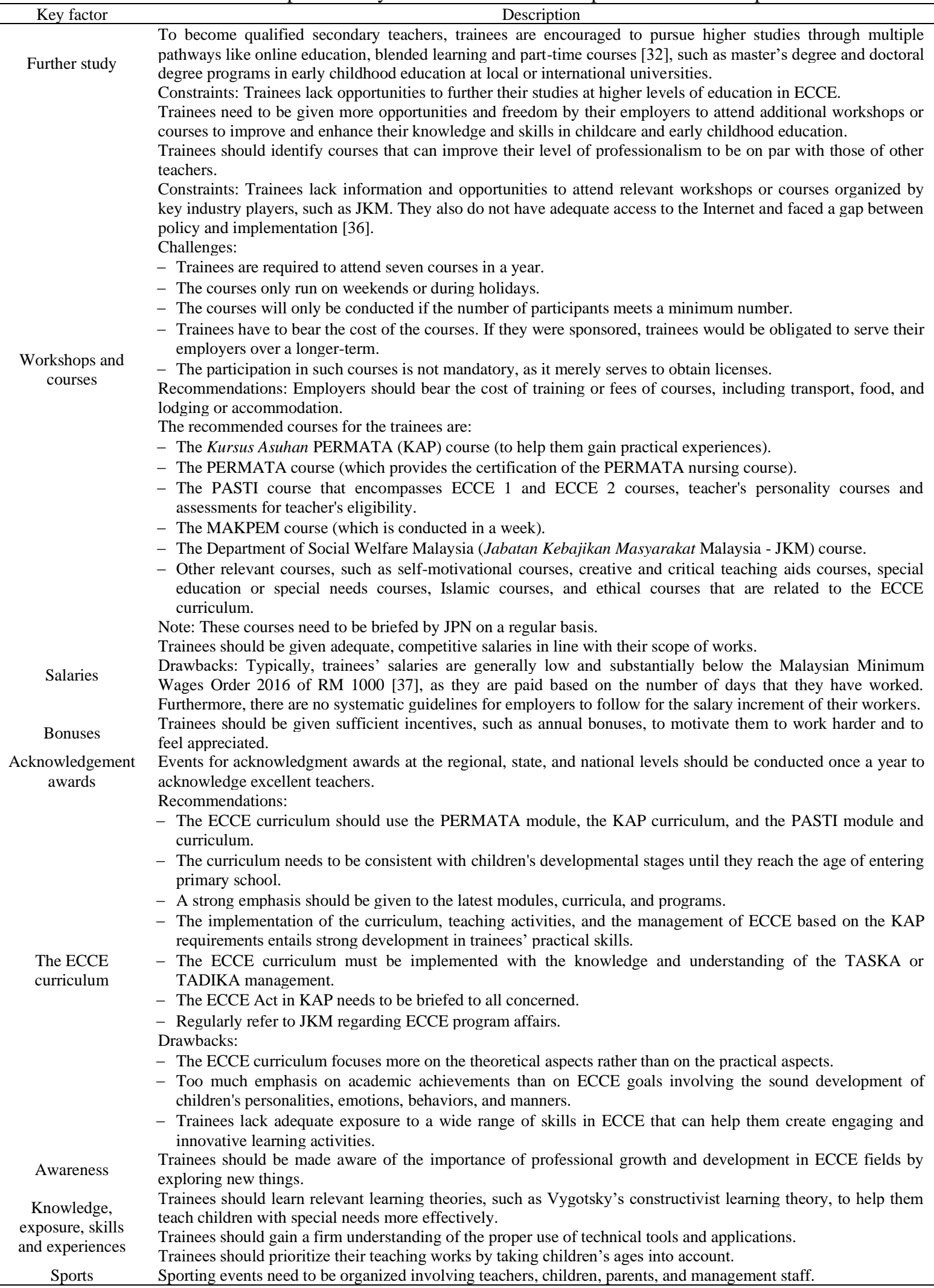

As revealed, employers need to provide support for their trainees in their professional growth and development, including competitive salaries, monetary incentives (such as bonuses), and acknowledgment awards. In addition, trainees should be given accurate information regarding available opportunities for their 
career path development through which they can upgrade their profession from being a teacher to a supervisor and to a manager or an owner of a childcare center. As highlighted by Dupree [38], by learning new skills like leadership, good governance, time management, communication management, team management and so forth can help to develop and shape their careers. Consequently, individual readiness along with employer's motivation and concerted efforts from all agencies are important factors that must work together to embrace future changes [32]. They should refer to a career pathway framework, which was conceptualized in this study as the Career Pathway Framework for ECCE, which can guide them to develop their profession to higher levels. Essentially, this framework comprises several key factors or concepts, namely, skills, goals, awareness, assessment, and performance.

Such a framework can help the stakeholders, particularly ECCE educators (teachers, trainees, and caretakers), to identify factors that can help practitioners to improve their professions by focusing on the opportunities, constraints, and recommendations related to their professional growth and development. Using such a framework, they can plan and take appropriate measures to equip themselves with relevant knowledge and skills that can help them become highly competent ECCE professionals. As such, this framework needs to be aligned with established standards to facilitate its implementation in all TASKA and TADIKA centers at the state and national levels, given that providers of ECCE services involve both public and private sectors. With no standards having been aligned with such a framework yet, more studies are, therefore, needed to determine the full impact of the Career Pathway Framework for ECCE on the current practice among practitioners.

\section{CONCLUSION}

Teaching and learning in the 21 st century are becoming more challenging as children need to learn new knowledge and acquire a new set of skills deemed essential in this technology-driven era. Likewise, ECCE teacher trainees need to learn new knowledge and acquire new skills to become effective teachers in the future. Surely, trainees should take appropriate measures to attain strong professional growth and development that focus on the acquisition of new knowledge, competencies, and short- and long-term goals through proper career path planning. In this study, a framework called Career Pathway Framework for ECCE was developed to highlight all aspects of the advancement of the professional growth and development of such trainees. The use of this framework can help trainees to focus on factors that can help them advance their career more effectively while their employers can focus on the types of support, encompassing both financial and motivational aspects, which can help their employees to achieve a rewarding, self-fulfilling career in ECCE.

\section{ACKNOWLEDGEMENTS}

This research entitled Development of a Comprehensive and Integrated Model of Quality Malaysian Early Childhood Care and Education (Code: 2015-0024-106-04), which is part of a larger project called Development of Careers-Educators' Professionalism (Code: 2015-0024-106-04-2) was fully-funded by Malaysia's Ministry of Finance through Malaysia's Ministry of Education. The researchers wish to extend their gratitude to the National Child Development Research Centre of Universiti Pendidikan Sultan Idris (UPSI), SEGI University, and all parties involved in this endeavor.

\section{REFERENCES}

[1] F. Marton and S. Booth, Learning and Awareness. Mahwah, NJ: Lawrence Erlbaum Associates, 1997.

[2] L. D. Fink, Creating Significant Learning Experiences: An Integrated Approach to Designing College Courses. San Francisco: Jossey-Bass Publishers, 2003.

[3] J. De Houwer, et al., "What is learning? On the nature and merits of a functional definition of learning," PsychonBull Rev., vol. 20, no. 4, pp. 631-642, 2013.

[4] S. M. Sheridan, et al., "Professional Development in Early Childhood Programs: Process Issues and Research Needs," Early Education and Development, vol. 20, no. 3, pp. 377-401, 2009.

[5] M. Taylor, "Understanding Stories of Professional Formation During Early Childhood Education and Care Practice Placements," Irish Educational Studies, vol. 37, no. 2, pp. 227-241, 2018.

[6] M. Savin-Baden and C. H. Major, Foundations of Problem-Based Learning. Berkshire, England: Society for Research into Higher Education. Open University Press, 2004

[7] G. Selvaraj, et al., "Current trends in Malaysian higher education and the effect on education policy and practice: An overview," International Journal of Higher Education, vol. 3, no. 1, pp. 85-93, 2014.

[8] A. Church and A. Bateman, "Methodology and Professional development: Conversation Analytic Role-Play Method (CARM) for early Childhood Education," Journal of Pragmatics, vol. 143, pp. 242-254, 2019. 
[9] J. Chen and C. Chang, "Using Computer in Early Childhood Classrooms: Teachers' attitudes, Skills and Practice," Journal or Early Childhood Research, vol. 4, no. 2, pp. 169-188, 2006.

[10] A. J. Stremmel, et al., "Communication, satisfaction, and Emotional Exhaustion among child care center staff: Directors, teachers and assistant teachers," Early Childhood Research Quarterly, vol. 8, pp. 221-233, 1993.

[11] K. M. Hall-Kenyon, et al., "Preschool Teacher Well-Being: A Review of the Literiture," Early Childhood Education Journal, vol. 42, pp. 153-162, 2014.

[12] S. Vartuli, et al., "Making it real: A Practice-Based Early Childhood Teacher Education Program," Early Childhood Education Journal, vol. 44, no. 5, pp. 503-514, 2016.

[13] P. F. Burke, et al., "Why do early teacher choose to remain in the profession? The use of best-worst scaling to quantify key factors," International Journal of Education Research, vol. 62, pp. 259-268, 2013.

[14] C. M. Wotipka, et al., "The worldwide expansion of early childhood care and education, 1985-2010," American Journal of Education, vol. 123, no. 2, pp. 1-14, 2017.

[15] K. Cheong, et al., "Employment as a journey or a destination? Interpreting graduates' and employers' perceptionsa Malaysia case study," Studies in Higher Education, vol. 43, no. 4, pp. 702-718, 2018.

[16] A. H. Masnan, et al., "New preschool teachers and implementation of inclusive classes issues in Malaysia," International Journal of Academic Research in Business and Social Sciences, vol. 7, no. 10, pp. 644-652, 2017.

[17] C. P. Brown, et al., The Wiley Handbook of Early Childhood Care and Education. New Jersey, United States: John Wiley \& Sons, 2019.

[18] A. Bhopti, et al., "Relationships between early childhood intervention services, family quality of life and parent occupations: A mixed-methods Australian study," Journal of Occupational Therapy, Schools, \& Early Intervention, vol. 13, no. 2, pp. 103-125, 2020.

[19] N. Nordin and M. A. Samsudin, "Professional Identity Formation in Globalization Era: Case of Malaysian Novice Teachers," Global Business \& Management Research, vol. 9, pp. 1-12, 2017.

[20] D. Adams, et al., "Teacher-parent collaboration for an inclusive classroom: Success for every child," MOJES: Malaysian Online Journal of Educational Sciences, vol. 4, no. 3, pp. 58-72, 2018.

[21] L. Foong, et al., "Private sector early child care and education in malaysia: workforce readiness for further education," Kajian Malaysia: Journal of Malaysian Studies, vol. 36, no. 1, pp. 1-13, 2018.

[22] D. Dupree, Definition of a Career Pathway. California, United States: Leaf Group Media Publication, 2018.

[23] Y. Xiaoyang, et al., "Parents'perspectives on school and family cooperation in primary schools: a case study in China," The Turkish Online Journal of Design, Art and Communication, vol. 7, pp. 1263-1269, 2018.

[24] D. Player, et al., "How principal leadership and person-job fit are associated with teacher mobility and attrition," Teaching and Teacher Education, vol. 67, pp. 330-339, 2017.

[25] S. Simon, "A Study of Primary School Parents' Interaction with Teachers' in Malaysia," World Academy of Science, Engineering and Technology International Journal of Educational and Pedagogical Sciences, vol. 11, no. 3, pp. 259-367, 2017.

[26] N. Mamat, et al., "Reliability, Validity and Fairness of Interviews for Teaching and Learning Project in Quality Early Childhood Care and Education: Preliminary Study," International Journal of Academic Research in Business and Social Sciences, vol. 8, no. 6, pp. 1-8, 2018.

[27] L. Heikonen, et al., "Early career teachers' sense of professional agency in the classroom: Associations with turnover intentions and perceived inadequacy in teacher-student interaction," Asia-Pacific Journal of Teacher Education, vol. 45, no. 3, pp. 250-266, 2017.

[28] Y. C. Soh, et al., "Students' views about a pharmacy franchise programmes in Malaysia: A qualitative study," Pharmacy Education, vol. 17, pp. 1-9, 2017.

[29] S. Schuck, et al., "The experiences of early career teachers: new initiatives and old problems," Professional Development in Education, vol. 44, no. 2, pp. 209-221, 2018.

[30] C. Boyce and P. Neale, "Conducting In-Depth Interviews: A Guide For Designing And Conducting In-Depth Interviews for Evaluation Input," Pathfinder International Tool Series, Monitoring and Evaluation, pp. 1-16, 2006.

[31] M. J. Neuman, et al., Early Childhood Care and Education Personnel in Low-and-Middle-Income Countries. France: UNESCO, 2015.

[32] L. Foong, et al., "Private sector early child care and education in Malaysia: Workforce readiness for further education," Kajian Malaysia, vol. 36, no. 1, pp. 127-154, 2018.

[33] L. Evans, "New theoretical perspectives on job satisfaction and motivation: Challenging Herzberg and linking with professional development," British Journal of Educational Studies, vol. 56, no. 1, pp. 20-38, 2010.

[34] C. Miller and L. Cable, Professionalization, Leadership and Management in the Early Years. London: SAGE Publications, 2011.

[35] L. Foong, et al., Early Child Care and Education in Malaysia: Towards Professionalization. Kuala Lumpur: Strategic Information and Research Development Centre, 2014.

[36] R. Berlin, 23 Challenges That All Early Childhood Educators Face in 2018. Research \& Technology, Teachstone Training, LLC, 2018. [Online]. Available: http://info.teachstone.com/blog/top-challenges-that-all-early-childhoodeducators-are-facing

[37] Federal Government Gazette. Minimum wages order 2016. P.U. (A) 116. Attorney General's Chamber, 2016. [Online]. Available: http://sta.org.my/images/staweb/New_Archived/2016/PerintahGajiMinimum2016.pdf

[38] D. Dupree, Definition of a Career Pathway. US: Leaf Group Media, 2018. 